\title{
Quality of meat from Santa Ines sheep with different biotypes and slaughtering weights
}

\section{Qualidade da carne de ovinos Santa Inês de diferentes biótipos e pesos de abate}

OLIVEIRA, Flávio Gomes de ${ }^{1}$; ; SOUSA, Wandrick Hauss de ${ }^{2} \mathbb{B}^{\circ}$; CARTAXO, Felipe Quiroga $^{3}$ (D) BATISTA, Ana Sancha Malveira ${ }^{4}$; ; RAMOS, João Paulo de Farias ${ }^{2}$ (D); CAVALCANTE, Iara Tamires Rodrigues ${ }^{1 *}$

${ }^{1}$ Universidade Federal da Paraíba-UFPB, Departamento de Zootecnia, Areia-PB, Brasil

${ }^{2}$ Empresa Estadual de Pesquisa Agropecuária da Paraíba-EMEPA, João Pessoa- PB, Brasil

${ }^{3}$ Universidade Estadual da Paraíba - UEPB,Departamento de Zootecnia, João Pessoa- PB, Brasil

${ }^{4}$ Universidade Estadual Vale do Acaraú - UVA, Departamento de Zootecnia Sobral-CE, Brasil

*Endereço para correspondência: iararodrigues16@hotmail.com

\begin{abstract}
The Santa Inês breed is of great importance for the lamb production chain in Brazil. The adaptive and reproductive characteristics of this breed favor its use in future breeding programs for the production of sheep for slaughter in northeastern Brazil. This study evaluated the carcass characteristics, physical parameters, chemical composition and determination of the fatty acid profile of the lambs of the traditional and modern biotypes, slaughtered at $32 \mathrm{~kg}$ and $34 \mathrm{~kg}$. Thirty-six Santa Inês lambs were used, with an average age of 180 days and initial weight of $16 \mathrm{~kg}$ in a completely randomized design, with a faecal spruce $2 \times 2$ (two biotypes and two slaughtering weights). The data were submitted to analysis of variance and averages were compared by the test $\mathrm{F} \alpha=$ 0.05 using SAS GLM, (2011) - Statistical Analysis System, version 9.3.Biotypes and slaughter weight did not influence the physical parameters and the fatty acid profile of the meat. Centesimal composition of meat was influenced by treatments, with the larger contents of meat moisture for the traditional biotype slaughtered at $32 \mathrm{~kg}$, and higher content of ash, protein and fat present in the meat for the modern biotype slaughtered at $34 \mathrm{~kg}$. Santa Inês animals that if frame Modern biotype presents potential for meat production with high nutritional value, due to higher protein content, low fat content and satisfactory amount of oleic, palmitic, stearic, linoleic fatty acids, as well as a great relationship between polyunsaturated acids and saturated.
\end{abstract}

Key words: Fatty Acids, Confinement, Lambs, Productive Efficiency, Semiarid

\section{RESUMO}

A raça Santa Inês é de grande importância para a cadeia de produção de cordeiros no Brasil. As características adaptativas e reprodutivas desta raça favorecem seu uso em futuros programas de melhoramento genético para a produção de ovinos para abate, no nordeste do Brasil. Este estudo avaliou características de carcaça, parâmetros físicos, a composição química e determinação do perfil de ácidos graxos da carne de cordeiros dos biótipos Tradicional e Moderno, abatidos com $32 \mathrm{~kg}$ e $34 \mathrm{~kg}$. Foram utilizados 36 cordeiros Santa Inês, não-castrados, com idade média de 180 dias e peso inicial de 16 
$\mathrm{kg}$ em delineamento inteiramente casualisado, com arranjo fatorial 2x2 (dois biotipos e dois pesos de abate). As dados foram submetidos a análise de variância e as médias foram comparadas pelo teste $\mathrm{F}$ a $\alpha=0,05$ com o uso de GLM do SAS, (2011) Statistical Analysis System, versão 9.3. Os biótipos e o peso de abate não influenciaram os parâmetros físicos e o perfil dos ácídos graxo da carne. Já a composição centesimal da carne foi influenciada pelos tratamentos, com os maiores teores de umidade na carne para o biótipo tradicional e abatidos aos $32 \mathrm{~kg}$, e maior teor de cinza, proteína e gordura presente na carne para o biótipo moderno abatido aos $34 \mathrm{~kg}$. Os animais da raça Santa Inês que se enquadram no biótipo Moderno apresentam potencial para produção de carne com alto valor nutricional, devido ao maior teor de proteínas, baixo teor de gordura e quantidade satisfatória de ácidos graxos oléico, palmítico, esteárico e linoleico, além de uma ótima relação entre ácidos poliinsaturados e saturados.

Palavras chaves: Ácidos graxos, Confinamento, Cordeiros, Eficiência Produtiva, Semiárido

\section{INTRODUCTION}

The Santa Ines breed is greatly important to the production chain of lamb meat in different regions of Brazil. This breed's adaptive and reproductive traits favor its use in future breeding programs to produce sheep for slaughter, in northeastern Brazil.

Over the years, several random breeding programs were carried out between Santa Ines and exotic breeds, especially Texel, Ile de France, Suffolk, Hampshire Down and Dorper, reducing the effective population of the "Traditional" Santa Ines genotype, which can lead to its disappearance in the long term. The increased frequency of these crossings gave rise to the Santa preservation actions by using these biotypes in the Northeastern semiarid.

In recent years, the search for healthy foods has raised important discussion points regarding production and quality of lamb meat, especially management methods, and meat nutritional characteristics. Meat is one of the main sources of protein, vitamins, minerals and a host of essential fats, including unsaturated fatty acids, omegas and conjugated linoleic acid (CLA) (Maia et al., 2012).
Ines "Modern" biotype, which is characterized by larger size animals, noticeably observed in the morphological structures such as head, ears, chest opening and heights of withers and croup, with accentuated body growth, on the increased fat and meat deposition on the carcass, and more demanding regarding the nutritional, sanitary and environmental aspects.

With these changes in the breed profile, in-depth knowledge of the Santa Ines "Traditional" and "Modern" biotypes is required to rescue the genetic basis of this breed, to know and compare the meat quality of different biotypes. The objective is to identify different traits that can add value and strengthen the Numerous factors affect meat quality, including, race, age, and weight at slaughter, they greatly influence the tissue and chemical composition. These factors are specific to each genotype, and their standardization favors more uniform carcasses, with great muscularity and fat finish. It is also noteworthy that the lipids physical and chemical properties affect meat nutritional quality and conservation (Madruga et al., 2006). This study had as objective evaluated the physical and chemistry composition and fatty acid 
profile of meat from Santa Ines sheep of biotype Traditional and Modern, slaughtered at $32 \mathrm{~kg}$ and $34 \mathrm{~kg}$.

\section{MATERIAL AND METHODS}

The experiment was conducted at the Experimental Station of Pendencia of Empresa Estadual de Pesquisa Agropecuária da Paraíba (EMEPA-PB), in Soledade, the mid-region of Cariri, located at $7^{\circ} 8^{\prime} 18^{\prime \prime} \mathrm{S}$ and $36^{\circ} 27^{\prime} 2^{\prime \prime} \mathrm{W}$, $534 \mathrm{~m}$ altitude and $30^{\circ} \mathrm{C}$ average temperature.

The experiment was approved by the Committee on Ethics in Animal Use CEUA - CBiotec of the Federal University of Paraíba (UFPB), with protocol: CEUA No. 2107/090. Thirty- six whole lambs of the Santa Inês biotypes were used, of which 18 were traditional and 18 were modern, with an average age of 180 days and a mean initial weight of $16 \mathrm{~kg}$. The lambs were housed in individual stalls of $0.80 \mathrm{x}$ $1.20 \mathrm{~m}$, with free access to food and water, until reached $32 \mathrm{~kg}$ and $34 \mathrm{~kg}$ slaughter weight during a period of maximum 70 days of confinement.

The supplied diet was formulated according to NRC (2007), to meet the requirements of sheep with $16 \mathrm{~kg}$ initial body weight and daily gain of 300 g/animal/day, with 30:70 roughage: concentrate ratio (Table 1). The adjustment period lasted 10daysand weighing was conducted every two weeks (14 days).

Table 1.Nutritional and chemical composition of the experimental diets

\begin{tabular}{|c|c|}
\hline Nutritional Ingredient $\left(\mathrm{g} \mathrm{kg}^{-1}\right.$ as fed) & Composition \\
\hline Tifton hay & 300.0 \\
\hline Ground corn & 481.0 \\
\hline Soybean meal & 180.0 \\
\hline Soybean oil & 20.0 \\
\hline Minerals* & 10.0 \\
\hline Calcitic limestone & 9.0 \\
\hline Chemical Component & Composition \\
\hline Dry matter $\left(\mathrm{g} \mathrm{kg}^{-1} \mathrm{DM}\right)$ & 886.4 \\
\hline Crude Protein ( $\left.\mathrm{g} \mathrm{kg}^{-1} \mathrm{DM}\right)$ & 167.6 \\
\hline Metabolizable energy (Mcal $\left./ \mathrm{kg}^{-1} \mathrm{DM}\right)$ & 2.80 \\
\hline Neutral detergent fiber $\left(\mathrm{g} \mathrm{kg}^{-1} \mathrm{DM}\right)$ & 318.5 \\
\hline Total digestible nutrients $\left(\mathrm{g} \mathrm{kg}^{-1} \mathrm{DM}\right)$ & 774.6 \\
\hline Ether extract $\left(\mathrm{g} \mathrm{kg}^{-1} \mathrm{DM}\right)$ & 48.46 \\
\hline Non-fibrous Carbohydrate $\left(\mathrm{g} \mathrm{kg}^{-1} \mathrm{DM}\right)$ & 419.02 \\
\hline Mineral material $\left(\mathrm{g} \mathrm{kg}^{-1} \mathrm{DM}\right)$ & 66.3 \\
\hline
\end{tabular}

The slaughter was performed in a slaughterhouse specific for small ruminants, belonging to the Pendência experimental station, EMEPA-PB. After reaching the pre-set slaughtering weight, the animals were put on an $18 \mathrm{~h}$ solid fasting and $12 \mathrm{~h}$ water fasting. Subsequently, they were stunned by concussion using a captive bolt pistol, suspended and slaughtered by cutting the jugular veins and carotid arteries for bleeding. Immediately after 
evisceration, the carcasses were identified/tagged, and the $\mathrm{pH}$ and the inner carcass temperature were measured in the Semimembranosus muscle at 0 hours post-mortem. Then, the carcasses were washed and hung by the Achilles tendons using appropriate hooks and cooled in cold storage at $4^{\circ} \mathrm{C}$ for 24 hours. After this period, carcass $\mathrm{pH}$ and temperature were measured again using a handheld $\mathrm{pH}$ meter, of Testo brand, model 205.In steps laters, after thaw, under temperature of $4 \pm 1$ ${ }^{\circ} \mathrm{C}$ for 24 hours, samples exempt visible connective tissue, were cut into $2 \mathrm{~cm}$ edge cubes (perpendicularly and longitudinally to the fibers) and subjected to grill cooking, Arno brand, preheated to $200^{\circ} \mathrm{C}$, to internal temperature (center of samples) of $71^{\circ}$ $\mathrm{C}$, measured with digital thermometer (Delta OHM model HD 9218, Caselle di Selvazzano, Italy). Then, the samples were placed in aluminum paper, identified and exposed to environment temperature to cool. After the cooling process, were weighed for determination of cooking weight loss (WLC) and again cut into $13 \mathrm{~mm}$ cubes for analysis of shear force (SF). The shear force determinations, indicative of meat hardness, were performed using a texturometer TA-XT2 (Surrey, England), equipped with a Warner Bratzler blade, operating at $20 \mathrm{~cm} / \mathrm{min}$ according to the methodology described by Duckett et al. (1998). Peak shear force was registered and the result expressed in $\mathrm{Kgf} / \mathrm{cm} 2$.

The meat color was determined at three different points in the Longissimus dorsi muscle, using the Minolta CR-200® colorimeter, and the $\mathrm{L}^{*}, \mathrm{a}^{*}$ and $\mathrm{b}^{*}$, lightness/brightness, redness, and yellowness, respectively, were also measured. Samples of longissimus muscle were packed and stored in a freezer at $-20{ }^{\circ} \mathrm{C}$ for 30 days for the following analyses: proximate chemical composition (ash, moisture, protein, lipids). All chemical analyses were done in triplicate, using methodology adapted from Madruga et al. (2001). The moisture, ash and protein contents were determined according to the AOAC (2000), using methods 985.41,920.153 and 928.08, respectively. The total lipids were measured according to the methodology described by Folch et al. (1957). Thirty milliliters of a chloroform-methanol $(2: 1 \mathrm{v} / \mathrm{v})$ mixture were added to $2 \mathrm{~g}$ of weighed sample. The mixture was stirred for 2 minutes using a Biomatic vortex, and then filtered using qualitative filter paper. After filtration, the wall of the vial containing the sample was washed with $10 \mathrm{~mL}$ of the solvent mixture, which was subsequently filtered and added to the first filtrate. The final volume was recorded.

To determine the profile of fatty acids the lipid extract obtained during the determination of total fat was used, following the methodology described by Hartman \& Lago (1973).Fatty acid esters were identified and quantified by gas chromatography (VARIAN 430GC, California, USA), equipped with flame ionization detector (FID), $60 \mathrm{~m} \mathrm{x}$ $0.25 \mathrm{~mm}$ silica fused capillary column (CP WAX 52 CB, VARIAN) and film thickness of $0.25 \mu \mathrm{m}$. Chromatograms were recorded by Galaxie Chromatography Data System software. Fatty acids were identified by comparing the retention times of the methyl esters of the samples with Supelco ME19-Kit standards (methyl esters of C6-C22 fatty acids).

The experimental design was completely randomized (DIC) in a $2 \times 2$ factorial scheme (2 biotypes $\times 2$ slaughtering weights), with no covariate effect. After defining the mathematical model, the residual analysis was performed to verify if all the assumptions of normality, independence 
and homogeneity between the residues were satisfied. We chose to use the Shapiro-Wilk test to verify the normality assumption of the residues; Durbin-Watson tests to test residue independence, and for homogeneity of variances, the Levene test. All at 0.05 significance level. For greater accuracy studied variables, the coefficient of variation (CV) was replaced by the index of variation (IV) according to ZIMMERMANN, (2014). The least squares method was used to determine the fatty acid profile, assuming the DIC. As there was no interaction among the factors, the means were compared by the test F a $\alpha=0.05$ with the GLM use of the SAS, (2011) - Statistical Analysis System, version 9.3.

\section{RESULTS AND DISCUSSION}

There was no interaction effect between biotypes and slaughter weights (P> 0.05). Thus, the variables are presented independently (Table 2).

Immediately post-mortem, carcass temperature was similar for both biotypes $(\mathrm{P}>0.05)$, which reduced from 34.9 and $35.12^{\circ} \mathrm{C}$ to 5.70 and $6.79^{\circ} \mathrm{C}$ for Traditional and Modern biotypes, respectively, after 24 hours. After cooling for 24 hours, the Modern biotype displayed a higher temperature $(\mathrm{P}<0.05)$ than the Traditional. The temperature of the Traditional biotype is lower possibly because less subcutaneous fat results in higher heat loss to the environment.

This result suggests that as the slaughter weight increases, the carcasses have higher amounts of subcutaneous fat that act as a thermal insulator so that the carcass remains hot for a longer time. This relationship was also observed by Bonagurio et al. (2003). These authors studied different slaughter weights (15, 25,35 , and $45 \mathrm{~kg}$ ) and reported that the heavier the animal, the lower the temperature drop. A sharp drop in temperature and $\mathrm{pH}$ accelerates the biochemical changes at post mortem and the action of proteolytic enzymes on the sensory attributes of the meat (Costa et al., 2011).

Table 2. Physical parameters of Santa Ines lamb meat according to biotype and slaughtering weights

\begin{tabular}{|c|c|c|c|c|c|c|c|}
\hline \multirow{2}{*}{ Parameters } & \multicolumn{3}{|c|}{ Biotypes } & \multicolumn{3}{|c|}{ Weight (kg) } & \multirow{2}{*}{ IV $(\%)$} \\
\hline & Traditional & Modern & $\mathrm{P}$ & 32 & 34 & $\mathrm{P}$ & \\
\hline Temperature $0 \mathrm{~h}$ & 34.9 & 35.12 & 0.678 & $34.1^{b}$ & $35.9^{\mathrm{a}}$ & 0.008 & 1.02 \\
\hline Temperature $24 \mathrm{~h}$ & $5.70^{\mathrm{b}}$ & $6.79^{\mathrm{a}}$ & 0.017 & 6.33 & 6.16 & 0.683 & 4.88 \\
\hline $\mathrm{pH} 0 \mathrm{~h}$ & $6.49^{\mathrm{b}}$ & $6.66^{\mathrm{a}}$ & 0.008 & $6.71^{\mathrm{a}}$ & $6.45^{\mathrm{b}}$ & $<0.001$ & 0.62 \\
\hline $\mathrm{pH} 24 \mathrm{hs}$ & 5.55 & 5.60 & 0.195 & $5.48^{b}$ & $5.67^{\mathrm{a}}$ & 0.001 & 0.53 \\
\hline $\mathrm{L}^{*}$ & 47.8 & 47.64 & 0.900 & 47.17 & 48.30 & 0.497 & 1.21 \\
\hline$a^{*}$ & 9.11 & 8.70 & 0.642 & 8.72 & 9.09 & 0.669 & 3.82 \\
\hline$b^{*}$ & 6.75 & 7.35 & 0.275 & 7.07 & 7.03 & 0.936 & 2.95 \\
\hline $\mathrm{SF}^{(\mathrm{kgf} / \mathrm{cm} 2)}$ & 3.53 & 3.36 & 0.555 & 3.56 & 3.32 & 0.379 & 5.61 \\
\hline $\mathrm{WLC}^{(\mathrm{g} / 100 \mathrm{~g})}$ & 40.62 & 40.90 & 0.744 & 41.01 & 40.97 & 0.308 & 0.91 \\
\hline $\mathrm{WHC}^{(\mathrm{g} / 100 \mathrm{~g})}$ & 67.13 & 66.96 & 0.903 & 67.23 & 66.86 & 0.782 & 2.13 \\
\hline
\end{tabular}

Means followed by the same letters in the row differ by $\mathrm{F}$ test $(\mathrm{P}<0.05) . \mathrm{P}=$ probability; $\mathrm{SF}=$ shear force; WLC $=$ weight loss by cooking; WHC $=$ water holding capacity; IV $=$ Index of variance. 
Between the biotypes there was difference initial $\mathrm{pH}$ ( $\mathrm{pH} 0$ hours) and, between slaughter weights, for initial and final $\mathrm{pH}$ ( $\mathrm{pH} 24$ hours), with values ranging from 6.45 to 6.71 for initial $\mathrm{pH}$ and 5, 67 to 5.548 for the final $\mathrm{pH}$ between biotypes and slaughter weights. Therefore, these presented values are within the limits considered normal for the species, from 5.5 to 5.8, according to Zeola et al. (2007), indicating that they difficultly present problems in meat related to $\mathrm{pH}$ and to stress preslaughter. Importantly these values considered normal for $\mathrm{pH}$ decrease evidence that other physical parameters of meat quality, as color, softness, water retention capacity, cooking weight loss and shear force were, not influenced by $\mathrm{pH}$.

According to Vieira et al. (2010), cold carcass is considered normal when $\mathrm{pH}$ is in the range 5.5 to 5.8 . The lamb meat, when are in this range, rarely presents problems related to $\mathrm{pH}$, such as the appearance of dried, dark and hard or pale, soft and dripping meat. Therefore, the $\mathrm{pH}$ is a determining factor in meat quality traits such as color, water-holding capacity and other quality attributes. Corroborating these authors, Silva Sobrinho et al. (2005) stated that the normal $\mathrm{pH}$ range from 5.5 to 5.8 yields a good relationship in the transformation process of muscle into meat. Therefore, the $\mathrm{pH}$ is a determining factor in meat quality traits such as color, water holding capacity, and other attributes. For Bonagurio et al. (2003), the pH is affected by weight gain and drops less sharply in animals slaughtered with less weight. These authors reported a sharper $\mathrm{pH}$ drop for Santa Ines meat compared to Texel and concluded that the $\mathrm{pH}$ between sheep breeds is different.

Color, shear force, cooking loss and water holding capacity were not influenced by biotypes nor slaughter weight $(\mathrm{P}<0.05)$. The lightness $\left(\mathrm{L}^{*}\right)$ values varied from 47.17 to 48.30 ; redness $\left(\mathrm{a}^{*}\right)$ from 8.70 to 9.11 ; and yellowness $\left(b^{*}\right)$ from 6.75 to 7.03 , for the evaluated biotypes. These colors reflect bright red meat, corroborating the results obtained by Bonagurio et al. (2003), for males and females of Santa Inês breed, slaughtered with different weights.

Studies carried out with Santa Ines and Bergamacia breeds showed that the meat color is similar. However, the values of $\mathrm{L}^{*}, \mathrm{a}^{*}$ and $\mathrm{b}^{*}$ may differ with weight gain since the increased muscle mass results in improved blood flow and high concentration of pigments (Bonagurio et al., 2003).

The shear force was similar for both biotypes and slaughter weight $(\mathrm{P}>0.05)$, ranging from 3.32 to 3.56 . The results presented in this study were below those found by Costa et al. (2011), at what the averages varied from 4.9 to $5.4 \mathrm{kgf} / \mathrm{cm}^{2}$ of the shear force of lambs of different genotypes and fed with two relations roughage: concentrated.

Cezar and Sousa (2007) stated that meat with shear force less than $2.27 \mathrm{kgf} / \mathrm{cm} 2$ is considered tender. Moreover, meat tenderness is classified as average when shear force values are between 2.27 and $3.63 \mathrm{kgf} / \mathrm{cm}^{2}$, within the acceptable range. Meat with shear force of 3.63 $\mathrm{kgf} / \mathrm{cm}^{2}$ is considered hard and, higher than $5.44 \mathrm{kgf} / \mathrm{cm} 2$, extremely hard. Therefore, the results found in this shear force research are directly related to meat tenderness, easily perceptible by taste sensations, facilitated by chewing, tooth penetration and rupture of muscle fibers throughout this process and at the end, the remaining sensation in the mouth.

Weight loss by cooking (WLC) ranged from 40.62 to $41.01 \mathrm{~g} / 100 \mathrm{~g}$ for the Traditional biotype slaughtered at 32 $\mathrm{kg}$, showing no difference between the studied effects $(\mathrm{P}>0.05)$. Probably, this 
similarity can be attributed to the fact that the animals of both biotypes were about the same age and physically similar, which may suggest that their differences are merely morphological.

These values are higher than the average $20 \mathrm{~g} / 100 \mathrm{~g}$ for WLC reported by Fernandes et al. (2011) for Santa Ines meat, highlighting that this value may be related to the amount of fat present in the meat. Other factors may be related to this change, especially preand post-slaughtering management, methodology, types of equipment, temperature and cooking time.

Meat water holding capacity varied between 66.86 and $67.23 \mathrm{~g} / 100 \mathrm{~g}$ $(\mathrm{P}>0.05)$ for the slaughter weights of 34 and $32 \mathrm{~kg}$, and between 67.13 and 66.96 for the Traditional and Modern biotypes, respectively, with no significant statistical differences. These results indicate that the evaluated meat is not dry or stiff since the water retention capacity is very important in the qualitative characteristics of meat (Fernandes et al., 2011). Furthermore, it is related to the amount of water present in the actin-myosin chains of the muscle which, when transformed into meat, gives the sensation of juiciness or presence of water in the chewing process (Batista et al., 2013).

There was no interaction effect $(\mathrm{P}<0.05)$ between biotypes and slaughter weight on the proximate composition of Santa Ines meat (Table 3). On the other hand, there was a significant difference $(\mathrm{P}<0.05)$ between biotypes for moisture, ash and protein percentages; while between slaughter weights, differences were observed only for moisture and lipids. Traditional biotype sheep and those slaughtered at $32 \mathrm{~kg}$ yielded meat with moisture content higher than the modern biotype or those slaughtered at $34 \mathrm{~kg}$. These moisture results are within the average range reported by Madruga et al. (2006) of $75 \mathrm{~g} / 100 \mathrm{~g}$ for the meat of Santa Ines lambs slaughtered at about 7 months old, and average slaughter weight of $90 \mathrm{~kg}$. Probably, because younger animals have higher water content in the meat, unlike older and heavier animals when the higher fat deposition lowers the water content.

Table 3. Chemical composition of meat from St Ines sheep of different biotypes and slaughter weights

\begin{tabular}{|c|c|c|c|c|c|c|c|}
\hline \multirow{2}{*}{$\begin{array}{l}\text { Components } \\
(\mathrm{g} / 100 \mathrm{~g})\end{array}$} & \multicolumn{3}{|c|}{ Biotypes } & \multicolumn{3}{|c|}{ Weight (Kg) } & \multirow{2}{*}{ IV (\%) } \\
\hline & Traditional & Modern & $\mathrm{P}$ & 32 & 34 & $\mathrm{P}$ & \\
\hline Moisture & $72.9^{a}$ & $72.09^{b}$ & $<0.001$ & $72.71^{\mathrm{a}}$ & $72.33^{b}$ & 0.074 & 0.28 \\
\hline Ash & $1.1^{\mathrm{b}}$ & $1.13^{\mathrm{a}}$ & 0.041 & 1.12 & 1.09 & 0.085 & 1.48 \\
\hline Proteins & $21.2^{\mathrm{b}}$ & $23.04^{\mathrm{a}}$ & $<0.001$ & 22.63 & 22.63 & 0.932 & 0.85 \\
\hline Lipids & 3.73 & 3.73 & 0.989 & $3.53^{\mathrm{b}}$ & $3.95^{\mathrm{a}}$ & 0.001 & 3.25 \\
\hline
\end{tabular}

Meat moisture content is related to quality, composition, meat processing, and even to carcass yield due to water losses during cooling, and it can affect directly meat juiciness, tenderness, texture, color, and flavor. According to Fernandes Junior et al. (2013b), young animals show higher amounts of water and lower fat, and the concentrations of protein, ash and water decrease with the age.

The ash content was higher for the Modern biotype, even though the two genotypes are genetically similar. On the other hand, Peixoto et al. (2011) studied different genetic groups of sheep (Dorper, Santa Ines, Somalis and non-defined breed) and found no 
difference in the ash content. They attributed the result to the genetic similarity between the groups.

The Modern biotype had higher protein content (23.04 g/100 g) while slaughtering weight did not affect this parameter $(\mathrm{P}>0.05)$. Similar to these values Santos et al. (2009), researching Santa Inês lambs in native pasture found average protein values of $22.33 \mathrm{~g} / 100 \mathrm{~g}$, considering this variable to be one of the most stable of centesimal composition.

The values found for proteins in this study corroborate those observed by Batista et al. (2010) and Costa et al. (2012) for meat of Santa Inês lamb, between 21 and $22.9 \mathrm{~g} / 100 \mathrm{~g}$.

The biotype did not influence the lipid content of lamb meat $(\mathrm{P}>0.05)$, the average $(3.73 \mathrm{~g} / 100 \mathrm{~g}$ of fat) was the same for both biotypes evaluated, and considered acceptable for human consumption, since as, with changes in the population's eating habits and concern for the quality of life, interest in leaner meat has increased (Macedo et al., 2008). Therefore, Santa Ines meat is attractive to the consumer, who is increasingly demanding about product quality regarding health related issues.

Animals slaughtered at $34 \mathrm{~kg}$ had higher fat content $(\mathrm{P}<0.05)$ and, as a result, less water in the meat. Naturally in slaughtered animals older and high weight, there is greater deposition of fat in the meat, because they are directly related.

A total of 30 fatty acids were identified, of which 13 saturated, 8 monounsaturated, and 9 polyunsaturated (Table 4). The fatty acids composition was also not affected by the biotypes and slaughter weights $(\mathrm{P}>0.05)$. The most representative saturated fatty acids were palmitic (C16:0), stearic (C18:0) and myristic (C14:0). Biotype and final weight had similar fatty acid profiles ( $\mathrm{P}>0.05$ ). Arruda et al. (2012), Madruga et al. (2006) and Fernandes et al. (2010), also studied Santa Ines sheep and reported similar results, drawing attention primarily to the palmitic, myristic and stearic saturated fatty acids because they stood out in the lipid profile of lamb meat. Though, these acids are associated with health problems, it is important to note that not all saturated acids increase bad cholesterol - LDL, the one with the highest hypercholesterolemic effect being the myristic acid (C14: 0), and of less effect the palmitic acid (C16:0) and in the case of stearic acid (C18: 0$)$ it has null effect, for it turns into oleic acid (C18:1) in the body and has hypocholesterolemic action, not reducing the blood levels of HDL cholesterol (ARRUDA et al., 2012; FERNANDES, M.A.M. et al., 2010; FRENCH et al. 2003; MAIA et al., 2012; SINCLAIR, 1993).

The percentages of saturated (SFA), monounsaturated (MUFA) and polyunsaturated (PUFA) fatty acids were not affected by biotypes nor the slaughter weight $(\mathrm{P}>0.05)$. The most representative monounsaturated acid in lamb meat was oleic (C18:1), with average percentage above $36 \mathrm{~g} / 100 \mathrm{~g}$. This fatty acid displayed the highest levels in the lamb meat for the studied biotypes and slaughter weights.

The evaluated biotypes did not affect significantly fatty acids profiles of the meat. However, it is observed that the meat has high amounts of saturated fatty acids, which are nutritionally undesirable. It is noteworthy that the mono and polyunsaturated fatty acids ratios/levels observed were very good. 
Table 4.Fatty acids levels and standard deviations, identified in the meat of Santa Ines sheep of different biotypes and slaughter weight

\begin{tabular}{|c|c|c|c|c|c|c|c|}
\hline \multirow{2}{*}{ Fatty acids } & \multicolumn{2}{|c|}{ Biotypes } & \multirow{2}{*}{$\mathrm{P}$} & \multicolumn{2}{|c|}{ Peso (kg) } & \multirow{2}{*}{$\mathrm{P}$} & \multirow{2}{*}{ IV (\%) } \\
\hline & Traditional & Modern & & 32 & 34 & & \\
\hline \multicolumn{8}{|c|}{ Saturated (SFA) } \\
\hline C6:0 & 0.02 & 0.02 & 0.761 & 0.01 & 0.03 & 0.063 & 23.58 \\
\hline C8:0 & 0.09 & 0.07 & 0.732 & 0.06 & 0.10 & 0.524 & 38.09 \\
\hline C10:0 & 0.15 & 0.15 & 0.834 & 0.14 & 0.16 & 0.362 & 7.81 \\
\hline C11:0 & 0.11 & 0.08 & 0.609 & 0.08 & 0.10 & 0.666 & 25.55 \\
\hline $\mathrm{C} 12: 0$ & 0.17 & 0.16 & 0.883 & 0.14 & 0.19 & 0.309 & 12.64 \\
\hline $\mathrm{C} 14: 0$ & 2.58 & 2.41 & 0.639 & 2.16 & 2.84 & 0.009 & 7.20 \\
\hline $\mathrm{C} 15: 0$ & 0.33 & 0.29 & 0.289 & 0.28 & 0.34 & 0.007 & 5.34 \\
\hline C16:0 & 25.37 & 22.55 & 0.215 & 22.04 & 25.89 & 0.102 & 4.38 \\
\hline $\mathrm{C} 17: 0$ & 0.88 & 0.38 & 0.455 & 0.82 & 0.90 & 0.209 & 3.67 \\
\hline C18:0 & 18.98 & 17.09 & 0.309 & 17.04 & 19.03 & 0.278 & 4.81 \\
\hline C20:0 & 0.75 & 0.12 & 0.354 & 0.73 & 0.13 & 0.379 & 72.32 \\
\hline $\mathrm{C} 23: 0$ & 0.07 & 0.05 & 0.590 & 0.04 & 0.08 & 0.334 & 34.37 \\
\hline $\mathrm{C} 24: 0$ & 0.19 & 0.20 & 0.723 & 0.19 & 0.19 & 0.868 & 5,79 \\
\hline \multicolumn{8}{|c|}{ Monounsaturated (MUFA) } \\
\hline $\mathrm{C} 14: 1 \mathrm{n} 5 \mathrm{c}$ & 0.13 & 0.12 & 0.510 & 0.11 & 0.14 & 0.120 & 7,52 \\
\hline $\mathrm{C} 16: \ln 7 \mathrm{c}$ & 1.80 & 1.77 & 0.913 & 1.74 & 1.82 & 0.738 & 6.58 \\
\hline $\mathrm{C} 17: \ln 7 \mathrm{c}$ & 0.48 & 0.54 & 0.489 & 0.54 & 0.48 & 0.568 & 8.74 \\
\hline $\mathrm{C} 18: \ln 9 \mathrm{c}$ & 36.43 & 42.87 & 0.209 & 42.00 & 37.30 & 0.338 & 6.52 \\
\hline $\mathrm{C} 18: \ln 9 \mathrm{t}$ & 2.15 & 2.16 & 0.962 & 2.21 & 2.10 & 0.687 & 4.77 \\
\hline $\mathrm{C} 18: \ln 11 \mathrm{c}$ & 0.40 & 0.35 & 0.180 & 0.37 & 0.39 & 0.501 & 7.84 \\
\hline $\mathrm{C} 20: \ln 9 \mathrm{c}$ & 0.13 & 0.07 & 0.111 & 0.10 & 0.09 & 0.679 & 17.41 \\
\hline $\mathrm{C} 24: \ln 9 \mathrm{c}$ & 0.15 & 0.09 & 0.687 & 0.17 & 0.07 & 0.431 & 51.37 \\
\hline \multicolumn{8}{|c|}{ Polyunsaturated (PUFA) } \\
\hline C18:2n6n & 5.04 & 4.52 & 0.187 & 5.09 & 4.48 & 0.127 & 3.87 \\
\hline C18:3n6c & 0.12 & 0.10 & 0.679 & 0.11 & 0.11 & 0.977 & 24.82 \\
\hline $\mathrm{C} 18: 3 \mathrm{n} 3$ & 0.30 & 0.26 & 0.211 & 0.28 & 0.28 & 0.751 & 4.68 \\
\hline $\mathrm{C} 20: 2 \mathrm{n} 6 \mathrm{c}$ & 0.34 & 0.32 & 0.718 & 0.38 & 0.27 & 0.111 & 9.82 \\
\hline $\mathrm{C} 20: 3 \mathrm{n} 6 \mathrm{c}$ & 0.15 & 0.17 & 0.499 & 0.15 & 0.16 & 0.678 & 9.38 \\
\hline $\mathrm{C} 20: 3 \mathrm{n} 3 \mathrm{c}$ & 1.77 & 1.60 & 0.509 & 1.90 & 1.47 & 0.111 & 7.36 \\
\hline $\mathrm{C} 20: 5 \mathrm{n} 3 \mathrm{c}$ & 0.15 & 0.27 & 0.499 & 0.12 & 0.29 & 0.355 & 40.1 \\
\hline $\mathrm{C} 22: 2 \mathrm{n} 6 \mathrm{c}$ & 0.06 & 0.08 & 0.789 & 0.10 & 0.04 & 0.231 & 35.38 \\
\hline $\mathrm{C} 22: 6 \mathrm{n} 3$ & 0.67 & 0.67 & 0.879 & 0.84 & 0.51 & 0.127 & 14.96 \\
\hline
\end{tabular}

$\mathrm{P}=$ probability of difference between treatments by $\mathrm{F}$ test $(\mathrm{P}<0.05) ; \mathrm{IV}=$ Index of variance.

Although the fatty acid profiles were similar for the two biotypes, these can change, thus changing the value depending on the genotype, age e weight (Costa et al., 2009). Corroborating these authors, Madruga et al. (2006) reported the pure breed is one of the factors that may influence the levels of monounsaturated and polyunsaturated acids.

In research whit different genetic groups of sheep, Maia et al. (2012) reported similar results to this research and considers sheep meat with these results of high nutritional value meat due to its low-fat content and satisfactory polyunsaturated and 
saturated fatty acids ratio, compared to meat of other species.

Lamb meat has several polyunsaturated acids, especially linoleic and linolenic acids, omega-6 (C18:2) and omega-3 (C18:3). It is worth mentioning the other fatty acids present in small amounts since the human body is not capable of synthesizing them and, they should be ingested in the diet (SALDANHA \& GONZALES, 2012).

Polyunsaturated fatty acids are present in both animal and vegetable foods. Some of them such as omega-3 and omega- 6 are unable to be produced by the human body, it is necessary to consume through diet in proper proportions to promote essential functions in the body (MARTIN et al. 2006).
Guinea and Henriques (2011) stated that it is important to maintain a balance between omega- 3 and omega- 6 acids, so they can work together to benefit health. The deficiency of essential fatty acids due to imbalance between omega 3 and 6 can trigger diseases, such as heart attack, cancer, asthma, schizophrenia, depression, vascular accident (CVA), obesity, diabetes, Alzheimer's and others.

The ratios between saturated, monounsaturated and polyunsaturated fatty acids indicate the health benefits to the consumer (Table 5). The mean ratios PUFA:SFA,MUFA:SFA, desirable fatty acid (DFA), n6: n3, atherogenicity index (AI) and the ratio (C18:0 + C18:1): C16:0 were similar for the biotypes and slaughter weights (P $<0.05)$.

Table 5. Saturated (SFA), monounsaturated (MUFA) and polyunsaturated (PUFA) fatty acids ratios for meat of Santa Ines sheep of different biotypes and slaughter weights

\begin{tabular}{lcccccccc}
\hline \multirow{2}{*}{ Fatty acids } & \multicolumn{2}{c}{ Biotypes } & \multirow{2}{*}{$\mathrm{P}$} & \multicolumn{2}{c}{ Weight $(\mathrm{kg})$} & \multirow{2}{*}{$\mathrm{P}$} & $\mathrm{IV}$ \\
\cline { 2 - 3 } & Traditional & Modern & & & 32 & 34 & & $(\%)$ \\
\hline PUFA:SFA & 0.181 & 0.179 & 0.087 & & 0.204 & 0.157 & 0.104 & 5.13 \\
MUFA:SFA & 0.907 & 1.074 & 0.158 & & 1.066 & 0.916 & 0.187 & 5.27 \\
DFA $^{1}$ & 69.237 & 72.687 & 0.192 & & 72.911 & 69.013 & 0.093 & 1.73 \\
n-6: n-3 & 1.881 & 1.757 & 0.596 & & 1.782 & 1.855 & 0.321 & 4.33 \\
AI $^{2}$ & 0.577 & 0.327 & 0.354 & & 0.312 & 0.592 & 0.267 & 26.31 \\
$(\mathrm{C} 18: 0+\mathrm{C} 18: 1): \mathrm{C} 16: 0$ & 2.428 & 2.743 & 0.122 & & 2.743 & 2.402 & 0.146 & 3.89 \\
\hline
\end{tabular}

${ }^{1}$ Desirable fatty acids $=$ MUFA+PUFA $+\mathrm{C} 18: 0 ;{ }^{2}$ Atherogenicity index $=[(\mathrm{C} 12: 0+(4 * \mathrm{C} 14: 0)+\mathrm{C} 16: 0)] / \mathrm{sum}$ of unsaturated; IV = Index of variance.

Santos et al. (2013) suggests that most studies conclude that for overall health promotion, the Omega-6 / Omega-3 ratio should be lower than that currently found in the Western general population, so that experts advocate reducing that ratio by both the increase in consumption of Omega-3 and the reduction of Omega- 6 . In this study, this ratio was lower than the value recommended by those authors and described by Madruga et al. (2006) (0.27) for Santa Ines meat.
Fatty acids are directly related to blood cholesterol levels. Oleic acid (C18:1) helps lower blood cholesterol. Meanwhile, palmitic acid (C16:0) increases the levels of cholesterol and stearic acid (C18:0), which indirectly can be converted into oleic acid (C18:1).

The mean ((C18:0 + C18:1):(C16:0)) ratio ranged from 2.4 to 2.7 for all considered effects. This relationship is beneficial to human health when found in red meat. Arruda et al. (2012) 
reported similar values ranging from 2.62 to 2.67 for Santa Inês meat, thus corroborating the quality of the lipid fraction of Santa Ines meat observed in this study.

For the results presented in this search, it is important to emphasize these biotypes are in the differentiation phase, with different selection objectives for each biotype, which leads to differences between some of the variables in this study. Further research is needed regarding the differentiation between the Traditional and Modern Santa Ines biotypes, with greater number of animals and different categories of slaughtering weights, to support the discussion about the phenotypic differences and the current changes of the standard breed.

The biotypes and slaughter weights did not affect the quality characteristics of the meat, however, the meat with the highest protein and fat content was the morden biotype and slaughtered with the higher weight.

\section{REFERENCES}

ASSOCIATION OF ANALITICAL CHEMISTS - AOAC. Official methods of analysis. Washington, D.C: 2000. $1219 p$.

ARRUDA, P.C.L.; PEREIRA, E.S.; PIMENTEL, P.G.; BOMFIM, M.A.D.; MIZUBUTI, I.Y.; RIBEIRO, E.L.A.; REGADAS FILHO, J. G.L. Perfil de ácidos graxos no Longissimus dorsi de cordeiros Santa Inês alimentados com diferentes níveis energéticos. Semina:

Ciências Agrárias, v. 33, n. 3, 2012

BATISTA, A.S.M.; COSTA, R.G.; GARRUTI, D.D.S.; MADRUGA, M.S.; QUEIROGA, R.D.C.R.D.; ARAÚJO FILHO, J.T.D. Effect of energy concentration in the diets on sensorial and chemical parameters of Morada
Nova, Santa Inez and Santa Inez x Dorper Lamb meat. Revista Brasileira de Zootecnia, v. 39, n. 9, p. 2017-2023, 2010

BATISTA, A.S.M.; DA SILVA, A.C.F.; DE FREITAS

ALBUQUERQUE, L. Características Sensoriais Da Carne Ovina. EssentiaRevista de Cultura, Ciência e Tecnologia da UVA, v. 15, n. 1, 2013.

BONAGURIO, S.; PÉREZ, J.R.O.; GARCIA, I.F.F.; BRESSAN, M.C.; LEMOS, A.L.D.S.C. Qualidade da carne de cordeiros Santa Inês puros e mestiços com Texel abatidos com diferentes pesos. Revista Brasileira de Zootecnia, p. 1981-1991, 2003.

CEZAR, M.F.; SOUSA, W.H. Carcaças ovinas e caprinas: obtenção, avaliação e classificação. Uberaba: Agropecuária Tropical, v. 147, 2007.

COSTA, L.S.; SILVA, R.R.; SILVA, F.F.D.; CARVALHO, G.G.P.D.; SIMIONATO, J.I.; MARQUES, J.D.A.; SAMPAIO, C.B. Centesimal composition and fatty acids of meat from lambs fed diets containing soybean hulls. Revista Brasileira de Zootecnia, v. 41, n. 7, p. 1720-1726, 2012.

COSTA, R.G.; BATISTA, A.S.M.; AZEVEDO, P.S.D.; QUEIROGA, R.D.C.R.D.; MADRUGA, M.S.; ARAÚJO FILHO, J.T.D. Lipid profile of Lamb meat from different genotypes submitted to diets with different energy levels. Revista Brasileira de

Zootecnia, v. 38, n. 3, p. 532-538, 2009.

COSTA, R.G.; SANTOS, N.D.; SOUSA, W.H.; QUEIROGA, R.C.R.E.; AZEVEDO, P.S.; CARTAXO, F.Q. Qualidade física e sensorial da carne de 
cordeiros de três genótipos alimentados com rações formuladas com duas relações volumoso:

concentrado. Revista brasileira de

Zootecnia, v. 40, n. 8, p. 1781-1787, 2011.

DUCKETT, S.K.; KLEIN, T.A.; LECKIE, R.K. et al. Effect of freezing on calpastatin activity and tenderness of callipyge lamb. Journal of Animal

Science, v.76, n.7, p.1869-1874, 1998.

FERNANDES JÚNIOR, G.A.; LÔBO, R.N.B.; MADRUGA, M.S.; LÔBO, A.M.B.O.; VIEIRA, L.D.S.; FACÓ, O. Genotype effect on carcass and meat quality of lambs finished in irrigated pastures in the semiarid Northeastern Brazil. Arquivo Brasileiro de Medicina Veterinária e Zootecnia, v. 65, n. 4, p. 1208-1216, $2013 \mathrm{a}$.

FERNANDES JÚNIOR, F.; RIBEIRO, E.L.A.; MIZUBUTI, I.Y.; DA SILVA, L.D.F.; BARBOSA, M.A.A.F.; PRADO, O.P.P.; CONSTANTINO, C. Características de carcaça e qualidade da carne de cordeiros Santa Inês alimentados com torta de girassol em substituição ao farelo de algodão. Semina: Ciências Agrárias, v. 34, n. 2, 2013 b.

FERNANDES, A.R.M.; JUNIOR, O.; PREVIDELLI, M.A.; ORRICO, A.C.A.; VARGAS JUNIOR, F.M.D.; OLIVEIRA, A.B.D.M. Desempenho e características qualitativas da carcaça e da carne de cordeiros terminados em confinamento alimentados com dietas contendo soja grão ou gordura protegida. Revista Brasileira de

Zootecnia, p. 1822-1829, 2011.

FERNANDES, M.A.M.; MONTEIRO, A.L.G.; POLI, C.H.E.C.; BARROS, C.S.D.; ALMEIDA, R.D.; RIBEIRO, T.M.D. Composição tecidual da carcaça e perfil de ácidos graxos da carne de cordeiros terminados a pasto ou em confinamento. Revista Brasileira de Zootecnia, p. 1600-1609, 2010.

FRENCH, P.;O'RIORDAN, E.G.; MONAHAN, F.J. et al. Fatty acid composition of intra-muscular triacylglycerols of steers fed autum grass and concentrates. Livestock Production Science, p.307-317, 2003.

GUINEA, R. P.; HENRIQUES, F. O papel dos ácidos gordos na nutrição humana e desenvolvimentos sobre o modo como influenciam a saúde. Millenium, n. 40, p. 7-21, 2011. HARTMAN, L.; LAGO, R. C. Rapid preparation of fatty acid methyl esters from lipids. Laboratory practice, $v$. 22, n. 6, p. 475-6 passim, 1973.

MACEDO, V. P., GARCIA, C. A., SILVEIRA, A. C., MONTEIRO, A. L. G., MACEDO, F. D. A. F. D. \& SPERS, R. C. Composições tecidual e química do lombo de cordeiros alimentados com rações contendo semente de girassol em comedouros privativos. Revista Brasileira de Zootecnia, v.37, n. 10, p. 1860-1868, 2008.

MADRUGA, M.S.; ARAÚJO, W.O.; SOUSA, W.H.; CÉZAR, M.F.; GALVÃO, M.D.S.; CUNHA, M.D.G.G. Efeito do genótipo e do sexo sobre a composição química e o perfil de ácidos graxos da carne de cordeiros. Revista Brasileira de Zootecnia, v. 35, n. 4, p. 1838-1844, 2006.

MAIA, M.D.O.; COSTA, F.D.S.; SUSIN, I.; RODRIGUES, G.H.; FERREIRA, E.M.; PIRES, A.V.; MENDES, C.Q. Efeito do genótipo sobre a composição química e o perfil de ácidos graxos da carne de borregas. Revista Brasileira de 
Zootecnia, v. 41, n. 4, p. 986-992, 2012.

MARTIN, CLAYTON A.; ALMEIDA, V.V DE; RUIZ, R.M.; VISENTAINER J.E.L; MATSHUSHITA, M.; SOUZA, N. E. DE; VISENTAINER, J.V. Omega-3 and Omega6 polyunsaturated fatty acids: importance and occurrence in foods. Revista de Nutrição. v. 19; n. 6; p. 761-770, 2006.

NATIONALRESEARCHCOUNCIL NRC. Nutrient Requirement sof Small Ruminants: sheep, goats, cervids, and new world camelids. Washintgton, D.C.: National Academy of Science, 2007. 347p.

PEIXOTO, L.R.R.; BATISTA, A.S.M.; BOMFIM, M.A.D.; DE

VASCONCELOS, Â.M.; DE ARAÚJO FILHO, J.T. Características físicoquímicas e sensoriais da carne de cordeiros de diferentes genótipos terminados em confinamento. Revista Brasileira de Saúde e Produção Animal, v. 12, n. 1, 2011.

RAMOS, E.M.; GOMIDE, L.A.M. Avaliação da qualidade de carnes: fundamento e metodologias. UFV, 2007.

SANTOS, R.D.; GAGLIARDI, A.C.M.; XAVIER, H.T.; MAGNONI, C.D.; CASSANI, R.; LOTTENBERG, A.M.P.; FENELON, G. I Diretriz sobre o consumo de gorduras e saúde cardiovascular. Arquivos Brasileiros de Cardiologia, v. 100, n. 1, p. 1-40, 2013.

SANTOS, J.R.S.D.U.; PEREIRA FILHO, J.M.; SILVA, A.M.D.A.; CEZAR, M.F.; BORBUREMA, J.B.; SILVA, J.O.R. Composição tecidual e química dos cortes comerciais da carcaça de cordeiros Santa Inês terminados em pastagem nativa com suplementação. Revista Brasileira de Zootecnia, 2009.

SALDANHA, E.S.P.B.; GONZALES E. Enriquecimento de ácidos graxos na alimentação de poedeiras . Pesquisa \& Tecnologia, v. 9, n. 1, Jan-Jun 2012.

SINCLAIR, A.J. Dietary fat and cardiovascular disease: the significante of recent developments for the food industry. Food Australia, v.45, p. 226, 1993.

STATISTICAL ANALYSIS SYSTEM. Statistical analysis system: user's guide: statistics. Version 9.3. Cary: SAS Institute inc. 2011.

VIEIRA, T.R. DE L., CUNHA; M.G.G.; GARRUTTI, D.S.; DUARTE, T.F.; FÉLEX, S.S.S.; PEREIRA FILHO, J.M.; MADRUGA, M.S. Propriedades físicas e sensoriais da carne de cordeiros Santa Inês terminados em dietas com diferentes níveis de caroço de algodão integral (Gossypium hirsutum). Ciência e Tecnologia de Alimentos, v. 30, n. 2 , 2010.

ZEOLA, N. M. B., SOUZA, P. A., SOUZA, H. B. A. \& SILVA SOBRINHO, A. G. Parâmetros qualitativos da carne ovina: um enfoque à maturação e marinação. Revista Portuguesa de Ciências Veterinárias, p.215-224, 2007.

ZIMMERMANN, F.J.P. Estatística aplicada à pesquisa agrícola. $2^{\circ} \mathrm{Ed}$. Brasília, DF: EMBRAPA, 2014. 582p. 